\title{
Land Evaluation of Rice-Wheat Growing Soils of Central Plains of Punjab for Land Use Planning
}

\author{
Jaya N. Surya ${ }^{1 *}$, G.S. Sidhu ${ }^{1}$, T. Lal ${ }^{1}$, D. Singh ${ }^{1}$, R.P. Yadav ${ }^{1}$ and S.K. Singh ${ }^{2}$ \\ ${ }^{1}$ ICAR-National Bureau of Soil Survey and Land use planning, Regional Centre Delhi, \\ New Delhi-110012, India \\ ${ }^{2}$ ICAR- National Bureau of Soil Survey and Land use planning, Amravati road, \\ Nagpur -440033, India \\ *Corresponding author
}

\begin{tabular}{|l|}
\hline Ke y w o r d s \\
$\begin{array}{l}\text { Land evaluation, } \\
\text { Qualitative, } \\
\text { Quantitative, Rice- } \\
\text { wheat cropping } \\
\text { system }\end{array}$ \\
\hline Article Info \\
\hline $\begin{array}{l}\text { Accepted: } \\
\text { 17 December } 2018 \\
\text { Available Online: } \\
\text { 10 January } 2019\end{array}$ \\
\hline
\end{tabular}

\section{Introduction}

Evaluation of land resources is essential in order to know the potentials and help in identifying the areas suitable for agricultural use and information on soils and their properties have a great value for judging suitability for its uses. It has long been recognized that land suitability is assessed as part of a 'rational' cropping system (FAO, 1976) and optimizing the use of a piece of land for a specified use (Sys et al., 1991a,b) 
should be based upon its attributes (Rossiter, 1996). Land evaluation may be defined as the process of assessment of land performance when the land is used for specified purpose (FAO 1985) or as the methods to explain or predict the use potential of land (Van Diepen et al., 1991). Once this potential is determined, land use planning can proceed on a rational basis, at least with respect to what the land resource can offer (FAO 1993). However, land evaluation is a tool for strategic land use planning. It predicts land performance, both in terms of the expected benefits from the constraints to productive land use, as well as the expected environmental degradation due to these uses. Land evaluation is formally defined as the assessment of land performance when use for a specified purpose, involving the execution and interpretation of surveys and studies of land forms, soils, vegetation, climate and other aspects of land in order to identify and make a comparison of promising kind of land use in terms of applicable to the objective of the evaluation (FAO, 1976). Conceptually, land evaluation requires matching of the ecological and management requirements of relevant kinds of land use with land qualities, whilst taking local economic and social economic condition into account.

The rice-wheat is the principal cropping system in south Asian countries that occupies about 13.5 million hectares in the IndoGangetic Plains (IGP), of which 10 million hectares are in India (Mahajan and Gupta, 2009), This cropping system is dominant in most of the Northern states of Indian, such as Punjab, Haryana, Delhi, Uttar Pradesh, and also in Madhya Pradesh and Bihar, contributes to $75 \%$ of the national food grain production. Punjab ranks third in rice-wheat crop area of the country with a share 6.86 and 11.57 per cent to all India in rice and wheat, respectively (Anonymous, 2016). Punjab first in yield by producing $4596 \mathrm{~kg} /$ hectares.
(Anonymous, 2016). Jalandhar is one of the agriculturally potential districts and also one of the major rice-wheat growing districts of Punjab cultivated over different landform settings. Monotonous cropping system over a prolonged period leads to several problems, plateauing/decline crop productivity, soil degradation, lowering fertility status and groundwater depth. Though rice-wheat is widely grown in the region, till now studies involving evaluation of rice-wheat growing soils was not attempted to find out potentials and constraint. Keeping this in view, the present studies were undertaken to generate soil information in the district for systematic land use plan.

\section{Materials and Methods}

\section{Study area}

The study was carried in representative sites of rice-wheat cropping system in Jalandhar district of Punjab. Area lies in between $30^{\circ} 58^{\prime}$ $00^{\prime \prime}$ to $31^{0} 39^{\prime} 10^{\prime \prime} \mathrm{N}$ Latitude and $76^{\circ} 26^{\prime} 00^{\prime \prime}$ to $75^{\circ} 57^{\prime} 20^{\prime \prime} \mathrm{E}$ longitude. Jalandhar district is bounded by four districts. The west border of the district touches Kapurthala, east with Ludhiana district, the northern with Hoshiarpur and in south with Ferozepur Ludhiana District. The district covers to an extent of 266200 hectares Jalandhar district is one of the agriculturally potential district of Punjab under rice-wheat, rice-wheat/potato cropping system. Majority of area is under old flood plain followed by recent flood plain and active fold plain (adjoining Sutlej River).

\section{Climate}

The climate of the study area is semi-arid and monsoonic with severe summer and winter. The area receives an annual precipitation of $703 \mathrm{~mm}$ of which $70 \%$ was received during July to September. Mean maximum and mean minimum summer air temperature is $41{ }^{0} \mathrm{C}$ 
and $26{ }^{\circ} \mathrm{C}$, respectively. Mean maximum and mean minimum winter air temperature is 19 ${ }^{0} \mathrm{C}$ and $6{ }^{0} \mathrm{C}$, respectively. The mean annual air temperature is $23.3^{\circ} \mathrm{C}$ and the difference between man summer and mean winter temperature is more than $5{ }^{0} \mathrm{C}$. Hence, the district qualifies for 'Hyperthermic' soil temperature regime. The soil moisture control section remains dry for more than 90 cumulative days or 45 consecutive days in four months following summer solstice and qualifies for ustic soil moisture regime. The study area represents semi- arid monsoonic climate with distinct summer, winter and rainy seasons.

\section{Field survey}

A reconnaissance soil survey was conducted in rice-wheat growing soils of Jalandhar district as per the procedure outlined by AIS and LUS (1970) on 1:50000 scale. After traversing the area, based on the visual observations and variations in soil-site characteristics and physiographic settings, representative profile sites were selected following the procedure outlined by Soil Survey Division Staff (2006). Horizon-wise soil samples were collected upto $150 \mathrm{~cm}$ depth for laboratory analysis in representative profiles. Processed soil samples $(<2-\mathrm{mm})$ were analyzed for various physic-chemical properties following standard procedure (Black et al., 1965; Jackson, 1973; Subbaih and Asija, 1956; Olsen et al., 1954; Lindsay and Norvell, 1978). The soils were classified into the sub-group of Inceptisols, Entisols, and alfisols as per USDA soil taxonomy (Soil Survey Staff, 2014).

The data were interpreted using qualitative and quantitative methods of land evaluation. The quantitative methods include USDA land capability classification (Klingebiel and Montogomery, 1966) and suitability classification methods include Riquier's parameter approach (Riquier et al., 1970).

\section{Results and Discussion}

\section{Soil characteristics}

The site characteristics such as slope, erosion and drainage varied with the microtopographic situations, physiographic settings. The Morphological characteristics of the soils showed that most of the soils were deep to very deep having colour in the hue of $10 \mathrm{YR}$, value ranging from 2 to 7 and chroma of 1 to 6 in the study area. The soils of the study area were light olive yellow to very dark brown in colour and had single grain, crumb, angular and sub-angular blocky structure. Soils of old alluvial plains area well drained, sandy loam to loam and clay loam soils area most fertile soils of the study area and classified as Typic Haplustepts/ Ustifluvents (Pedon1, P2, P3). Soils of old alluvial plains with old levees $(\mathrm{P} 4$, P5) are well drained, sandy loam to loamy sand, calcareous soils. P4 (Gorshian Nihal) soils are relatively more developed than Talwan and intensively cultivated to rice and wheat crop. Talwan (P5) soils occurring along the levees and having fluventic characteristics and classified as Typic Ustorthents/ Ustifluvents. Soils of recent flood plains well drained to excessively drained, sandy loam to loamy sand to sand, calcareous soils (sandy to coarse loamy, Typic Ustorthents/ Ustipsamments). Soils of active flood plain (P8, P9) are light textured (loamy sand to sandy) soils, stratified calcareous, less fertile soils, even cultivated for rice and wheat only because of availability of water.

\section{Physico-chemical characteristics}

Most of the soils were sandy loam to loamy sand in surface horizons and sandy loam to clay loam to loamy sand in texture and in subsurface horizons. The clay content ranged from 1.99 to 39.13 per cent (Table 1). However, decrease of clay content with depth in soils was observed in most of the pedons 
which might be due to variability of weathering in different horizons. Similar trend of irregular decrease of clay was also reported by Sidhu et al., (2014) and Surya et al., (2018). The sand, silt and clay content varied from 45.03 to 94.05 per cent, 9.00 to 28.72 per cent $\%$ and 7.55 to 34.25 per cent, respectively. The Soils were near slightly alkaline to moderately in reaction $(\mathrm{pH} 7.1$ to 8.8) and strongly alkaline in patches. In general, $\mathrm{pH}$ of the soils did not show any specific trend. The organic carbon content of the soils varied from 0.12 to 0.76 per cent and decreased with depth. The Cation exchange capacity (CEC) in all the profiles followed the pattern of clay distribution in soil. Relatively low CEC is the reflection of parent material and higher degree of weathering leading to depletion of bases. Similar reports were reported by Surya et al., (2016). The per cent base saturation varied from 53.10 to 94.00. The variations in base saturation of the soils might be due to variation in nature and / or content of soil colloids. The higher base saturation observed in some pedons might be due to higher amount of $\mathrm{Ca}$ occupying exchange sites on the colloidal complex. Similar results were reported by Sidhu, et al., (2014).

\section{Land evaluation}

All the rice-wheat growing soils were evaluated by adopting qualitative or quantitative methods and the results discussed.

\section{Qualitative evaluation}

The qualitative evaluation of the soils for crop production has been carried out by two procedure viz., land capability and land suitability classification. In the present study, the land capability has been classified up to capability sub-classes based on their constraints and potentialities for sustained productivity by following USDA land capability classification.

Land capability systems have been designed to evaluate and communicate biophysical constraints on land use, including climatic limitations. By grading land quality, the resulting information is particularly relevant for planners and managers and for land valuation. Higher-class land is more flexible and has more options for land use therefore demonstrating a greater options; however land of a particular capability class also has the potential to be used as specified for any lower classes. Therefore, land capability systems can identify both the capacity of an area of land for different use and also the optimal use from a biophysical, as opposed to socioeconomic, perspective. The land capability assessment highlights not only potential changes in agriculture and other productive land uses, but repercussions for biodiversity and terrestrial carbon stocks. Land capability classification is based upon intrinsic biophysical limitations of the land i.e. those that cannot be removed or ameliorated by reasonable management, and therefore act as constraints to use.

The results on land capability classification indicated that pedons P1, P2, P3, and P6 on old alluvial plains and recent flood plains were classified under land capability sub-class IIs and IIsw with good potentials for cultivation of almost all the crops.

Pedons P4, P5, and P7 soils categorized into class IIIse due to constraints of erosion, texture, and inherent soils characteristics. Pedon P8, and P9 on active flood plains have limitations of slope, erosion, drainage, texture, and organic carbon and hence classified as IVes and IVs due to major limitations of drainage, sandy texture, organic carbon, base saturation and CEC. 
Suitability is a function of crop requirements and soil/ land characteristics. Matching the land characteristics with crop requirements gives the suitability. So, suitability is a measure of how well the qualities of a land unit match the requirements of a particular form of land use. Land suitability classification is the evaluation and grouping of specific area of land in terms of their suitability for a defined use. In the present study important soil-site characteristics (Table 2) were evaluated to determine the suitability of the rice-wheat growing soils and the results indicated that the overall suitability of most of the pedons (soils of old alluvial Plains) were suitable to moderately suitable (S1-S2) (P1, P2, P3, and P6), pedons P4, P5, and P8 were marginally suitable while $\mathrm{P} 7, \mathrm{P} 8$ and $\mathrm{P} 9$ (soils of active flood plains) were presently not suitable for growing rice and wheat crop with limitations of excessive drainage, coarser to sandy texture, slope, alkaline, low fertility and soil depth and with limitations of wetness, flooding.

The evaluation of soil-site suitability productivity and capability had revealed that, texture, alkalinity, low organic carbon and low CEC were the main limitations in majority of soil units. These limitations override other good qualities in these soils which bring them to lower classes. Erosion as a limitations can be controlled while effective depth and texture are of more permanent characteristics. Since these two properties are relevant to crop production, these soils must be properly managed in a sustainable way to ensure optimum production of crops of them. The use of crop residues, compost and cover are recommended as soil management strategies. Limitations imposed by soil chemical properties can be imaged by applying appropriate fertilizer use to control nutrient deficiency. Low CEC indicates that continues prolonged rice-wheat cultivation may not be feasible without adequate fertilizer application as the soils have limited ability to retain nutrients. If the soil organic matter is poor, it can be properly managed using crop residues, compost, trash mulching and vertical mulching with filter cake and inorganic fertilizer in combination with organics.

\section{Quantitative evaluation}

Quantitative evaluation is the assessment of land for its performance in relation to yield and economic variable for the specific use in question. In the present study, for the specific the evaluation was worked out using parametric approaches by Riquier et al., (1970) who suggested productivity index for evaluating soils for the commonly growing crops of the area. Accordingly, the productivity index for the rice-wheat growing soils under the study was calculated by considering nine factors which were related to soil productivity. The Data presented in the table 2 revealed that the actual productivity potential of the studied soils varied between low to high The lowest productivity potential was observed for pedons 8 and 9. In general, most of the pedons over old alluvial plains were categorized under the good productivity potential class. The suitability of soils for cultivation of rice and wheat was compared with the land capability and productivity (Table 3) to know whether a soil unit suitable for rice-wheat cultivation is also productive or not. The results of land evaluation revealed that soils with good fertility qualities in some cases have medium to poor production potential and vice-versa. making the suitability of rice-wheat crop for soil unit not ideal without management practices.

Present land use of soils of suitable for wheat and moderately to marginally suitable for rice (S2-S3) (Pedons 2, 4, 5, and 6) category is under cultivation with wheat, rice, potato, mustard, maize, pulses, and vegetables. 
Table.1 Physico-chemical properties of Soils of the study area

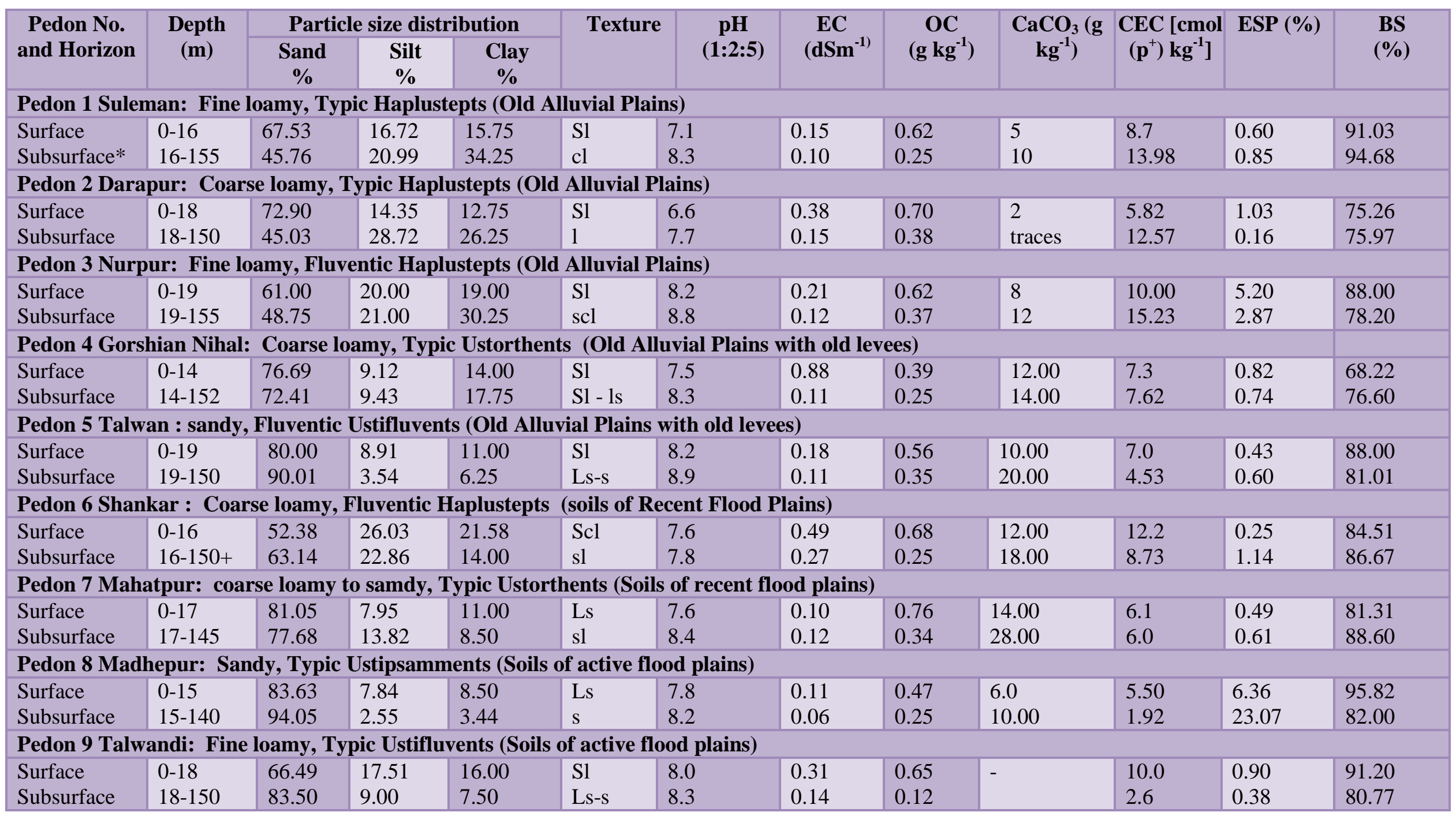

*Texture: S1 - sandy loam, cl - clay loam, scl - sandy clay loam, ls- loamy sand, s - sandy

* subsurface - weighted mean value of sub-surface samples 
Table.2 Soil-site characteristics selected for suitability evaluation

\begin{tabular}{|c|c|c|c|c|c|c|c|c|c|}
\hline Soil Profiles & P1 & $\mathbf{P 2}$ & P3 & P4 & P5 & P6 & P7 & P8 & P9 \\
\hline Landform & Old & uvial Plair & (OAP) & OAP with & Levees & Recent F & od Plains & Soils of Acti & Flood Plains \\
\hline Soil profiles & Suleman & Darapur & Nurpur & $\begin{array}{c}\text { Gorshian } \\
\text { Nihal }\end{array}$ & Talwan & Shankar & Mahetpur & Madhepur & Talwandi \\
\hline Soil-site charact & istics & & & & & & & & \\
\hline Slope(\%) & $\begin{array}{c}0-1 \\
(\mathrm{~S} 1)\end{array}$ & $\begin{array}{l}1-3 \\
(\mathrm{~S} 2)\end{array}$ & $\begin{array}{c}0-1 \\
(\mathrm{~S} 1)\end{array}$ & $\begin{array}{c}0-1 \\
(\mathrm{~S} 1)\end{array}$ & $\begin{array}{c}0-1 \\
(\mathrm{~S} 1)\end{array}$ & $\begin{array}{c}0-1 \\
(\mathrm{~S} 1)\end{array}$ & $\begin{array}{l}1-3 \\
(\mathrm{~S} 2)\end{array}$ & $\begin{array}{l}1-3 \\
(\mathrm{~S} 2)\end{array}$ & $\begin{array}{l}0-1 / 1-3 \\
(\mathrm{~S} 1)\end{array}$ \\
\hline Drainage & $\begin{array}{l}\text { Well } \\
\text { (S1) }\end{array}$ & $\begin{array}{l}\text { Well } \\
\text { (S1) }\end{array}$ & $\begin{array}{c}\text { Mod } \\
\text { Well drained } \\
\text { (S2) }\end{array}$ & $\begin{array}{c}\text { Somewhat } \\
\text { Ex.c Drained } \\
\text { (S3) }\end{array}$ & $\begin{array}{c}\text { Exc. } \\
\text { Drained } \\
(\mathrm{S} 3)\end{array}$ & $\begin{array}{l}\text { Well } \\
\text { drained } \\
(\mathrm{S} 2)\end{array}$ & $\begin{array}{c}\text { Exc. } \\
\text { Drained } \\
(\mathrm{S} 3)\end{array}$ & $\begin{array}{l}\text { Exc Drained } \\
\text { (S3) }\end{array}$ & $\begin{array}{l}\text { Some-what } \\
\text { Exc Drained }\end{array}$ \\
\hline Texture & Scl-cl & Sl-scl & Scl-1 & S1-ls & Sl-ls-s & sl & Ls-sl & Ls-s & S1-1s/s \\
\hline Depth $(\mathrm{cm})$ & $155+$ & $150+$ & 155 & 145 & 150 & $150+$ & 150 & 140 & 150 \\
\hline Clay (\%) & 34.25 & 26.25 & 24.62 & 14.9 & 8.63 & 17.79 & 10.54 & 3.45 & 11.74 \\
\hline $\begin{array}{l}\mathrm{CEC}\left[\mathrm{cmol}\left(\mathrm{p}^{+}\right)\right. \\
\left.\mathrm{kg}^{-1}\right]\end{array}$ & 13.98 & 12.57 & 15.23 & 7.62 & 4.53 & 8.73 & 6.0 & 1.92 & 2.6 \\
\hline $\begin{array}{l}\mathrm{EC} \\
\left(\mathrm{dS} \mathrm{m}^{-1}\right)\end{array}$ & 0.12 & 0.26 & 0.16 & 0.74 & 0.15 & 0.38 & 0.11 & 0.10 & 0.23 \\
\hline $\mathrm{pH}(1: 2: 5)$ & 8.0 & 7.5 & 8.8 & 7.9 & 8.5 & 7.7 & 8.2 & 8.0 & 8.2 \\
\hline ESP & 2.02 & 0.29 & 0.91 & 0.77 & 0.52 & 1.14 & 0.86 & 14.71 & 0.64 \\
\hline $\mathrm{OC}(\%)$ & 0.45 & 0.40 & 0.40 & 0.23 & 0.42 & 0.25 & 0.40 & 0.30 & 0.15 \\
\hline Suitability class & S1 & S1 & S1-S2 & S2-S3 & S2-S3 & S1-S2 & S3 & N1 & S3/N1 \\
\hline $\begin{array}{l}\text { Land Capability } \\
\text { class }\end{array}$ & IIs & IIs & IIsw & IIIse & IIIse & IIsw & IIIse & VIes & IVse \\
\hline $\begin{array}{l}\text { Production } \\
\text { Potentials }\end{array}$ & High & High & $\begin{array}{l}\text { Medium to } \\
\text { High }\end{array}$ & $\begin{array}{l}\text { Low to } \\
\text { medium }\end{array}$ & Low & $\begin{array}{c}\text { Medium to } \\
\text { High }\end{array}$ & $\begin{array}{l}\text { Low to } \\
\text { medium }\end{array}$ & Very Low & Low \\
\hline
\end{tabular}


Table.3 Comparative evaluation of capability, suitability and productivity of soil for alternate land use options

\begin{tabular}{|c|c|c|c|c|c|c|c|c|}
\hline \multirow{2}{*}{$\begin{array}{l}\text { Pedon } \\
\text { No. }\end{array}$} & \multirow{2}{*}{$\begin{array}{l}\text { Present } \\
\text { land use }\end{array}$} & \multirow{2}{*}{$\begin{array}{c}\text { Land } \\
\text { capability } \\
\text { classification }\end{array}$} & \multicolumn{2}{|c|}{ Soil-site suitability } & \multicolumn{2}{|c|}{ Production potential } & \multirow{2}{*}{$\begin{array}{l}\text { Management practices to be } \\
\text { adopted }\end{array}$} & \multirow{2}{*}{$\begin{array}{l}\text { Suggested land use after } \\
\text { adopting management } \\
\text { practice }\end{array}$} \\
\hline & & & Class & Constraints & Class & Constraints & & \\
\hline $\mathrm{P} 1$ & Rice-wheat & IIs & $\begin{array}{l}\text { Suitable } \\
\text { (S1) }\end{array}$ & $\begin{array}{l}\text { Depletion nutrients; } \\
\text { Depletion of ground } \\
\text { water; } \\
\text { Medium in fertility } \\
\text { Depletion nutrients }\end{array}$ & High & $\begin{array}{l}\text { Very good cultivable } \\
\text { lands. medium fertility } \\
\text { status }\end{array}$ & $\begin{array}{l}\text { Balanced fertilization (macro and } \\
\text { micronutrients); Light and frequent } \\
\text { irrigation } \\
\text { Transplanting paddy with the onset } \\
\text { of monsoon to save water; Proper } \\
\text { crop rotation and mix cropping }\end{array}$ & $\begin{array}{l}\text { Ideal to grow all } \\
\text { climatically adapted crops; } \\
\text { Present cropping system } \\
\text { may be continued with } \\
\text { incorporation of leguminous } \\
\text { crops to maintain soil health. }\end{array}$ \\
\hline $\mathrm{P} 2$ & Rice-wheat & IIs & $\begin{array}{l}\text { Suitable } \\
\text { (S1) }\end{array}$ & $\begin{array}{l}\text { Depletion nutrients; } \\
\text { Depletion of ground } \\
\text { water; } \\
\text { Medium in fertility } \\
\text { Depletion nutrients }\end{array}$ & High & $\begin{array}{l}\text { Very good cultivable } \\
\text { lands. medium fertility } \\
\text { status }\end{array}$ & $\begin{array}{l}\text { Balanced fertilization (macro and } \\
\text { micronutrients); Light and frequent } \\
\text { irrigation } \\
\text { Transplanting paddy with the onset } \\
\text { of monsoon to save water; Proper } \\
\text { crop rotation and mix cropping }\end{array}$ & $\begin{array}{l}\text { Agro-Horti-Floriculture } \\
\text { may be preferred; Ideal to } \\
\text { grow all climatically } \\
\text { adapted crops; Crop } \\
\text { rotations with pulses and } \\
\text { oilseeds may be included } \\
\text { - Transplanting paddy with } \\
\text { the onset of monsoon to } \\
\text { save water }\end{array}$ \\
\hline $\mathrm{P} 3$ & $\begin{array}{l}\text { Rice-wheat } \\
\text { mustard } \\
\text { /potato }\end{array}$ & IIsw & $\begin{array}{l}\text { Suitable to } \\
\text { Moderate } \\
\text { (S1-S2) }\end{array}$ & $\begin{array}{l}\text { Moderate drainage and } \\
\text { low fertility status }\end{array}$ & $\begin{array}{l}\text { Medium } \\
\text { to high }\end{array}$ & $\begin{array}{l}\text { Moderate drainage } \\
\text { and moderate } \\
\text { alkalinity, low } \\
\text { fertility status. }\end{array}$ & $\begin{array}{l}\text { Balanced fertilization (NPK and } \\
\text { micronutrients); Use of good quality } \\
\text { water for irrigation; } \\
\text { Proper crop rotation and mix } \\
\text { cropping, addition of amendments, } \\
\text { FYM/ green manuring with } \\
\text { legumes. }\end{array}$ & $\begin{array}{l}\text { Agro-Horti-Floriculture may } \\
\text { be preferred } \\
\text { Ideal to grow all } \\
\text { climatically adapted crops } \\
\text { Crop rotations with pulses } \\
\text { and oilseeds may be } \\
\text { included }\end{array}$ \\
\hline $\mathrm{P} 4$ & $\begin{array}{l}\text { Rice-wheat } \\
\text { mustard }\end{array}$ & IIIse & $\begin{array}{l}\text { Moderate } \\
\text { marginal } \\
(\mathrm{S} 2-\mathrm{S} 3)\end{array}$ & $\begin{array}{l}\text { Coarser texture soils, } \\
\text { low fertility, texture, } \\
\text { excessive drainage } \\
\text { conditions CEC and } \\
\text { ESP }\end{array}$ & $\begin{array}{l}\text { Medium } \\
\text { to low }\end{array}$ & $\begin{array}{l}\text { Moderate erosion, } \\
\text { exce. drainage } \\
\text { Coarse texture soil, } \\
\text { low fertility status. } \\
\text { Depletion of } \\
\text { underground water } \\
\text { and nutrients }\end{array}$ & $\begin{array}{l}\text { Improvement in soil fertility and } \\
\text { physical conditions by adding } \\
\text { organic fertilizers and manures } \\
\mathrm{N} \text {-fertilizers application in split } \\
\text { doses } \\
\text { - Light and frequent irrigations }\end{array}$ & $\begin{array}{l}\text { Cultivation of wheat, } \\
\text { mustard, potato, maize, and } \\
\text { pulses, vegetable crops Rice } \\
\text { may be avoided to check } \\
\text { groundwater depletion }\end{array}$ \\
\hline P5 & $\begin{array}{l}\text { Rice-wheat } \\
\text { mustard } \\
\text { /potato }\end{array}$ & IIIse & $\begin{array}{l}\text { Moderate to } \\
\text { marginal } \\
(\mathrm{S} 2-\mathrm{S} 3)\end{array}$ & $\begin{array}{l}\text { Coarser texture soils, } \\
\text { low fertility, texture, } \\
\text { excessive drainage } \\
\text { conditions CEC and }\end{array}$ & Low & $\begin{array}{l}\text { Moderate erosion, } \\
\text { excessive. drainage } \\
\text { Coarse texture to } \\
\text { sandy textured soil, }\end{array}$ & $\begin{array}{l}\text { Improvement in soil fertility and } \\
\text { physical conditions by adding } \\
\text { organic fertilizers and manures } \\
\mathrm{N} \text {-fertilizers application in split }\end{array}$ & $\begin{array}{l}\text { Cultivation of millets, } \\
\text { vegetables, pulses and } \\
\text { oilseeds can be preferred }\end{array}$ \\
\hline
\end{tabular}




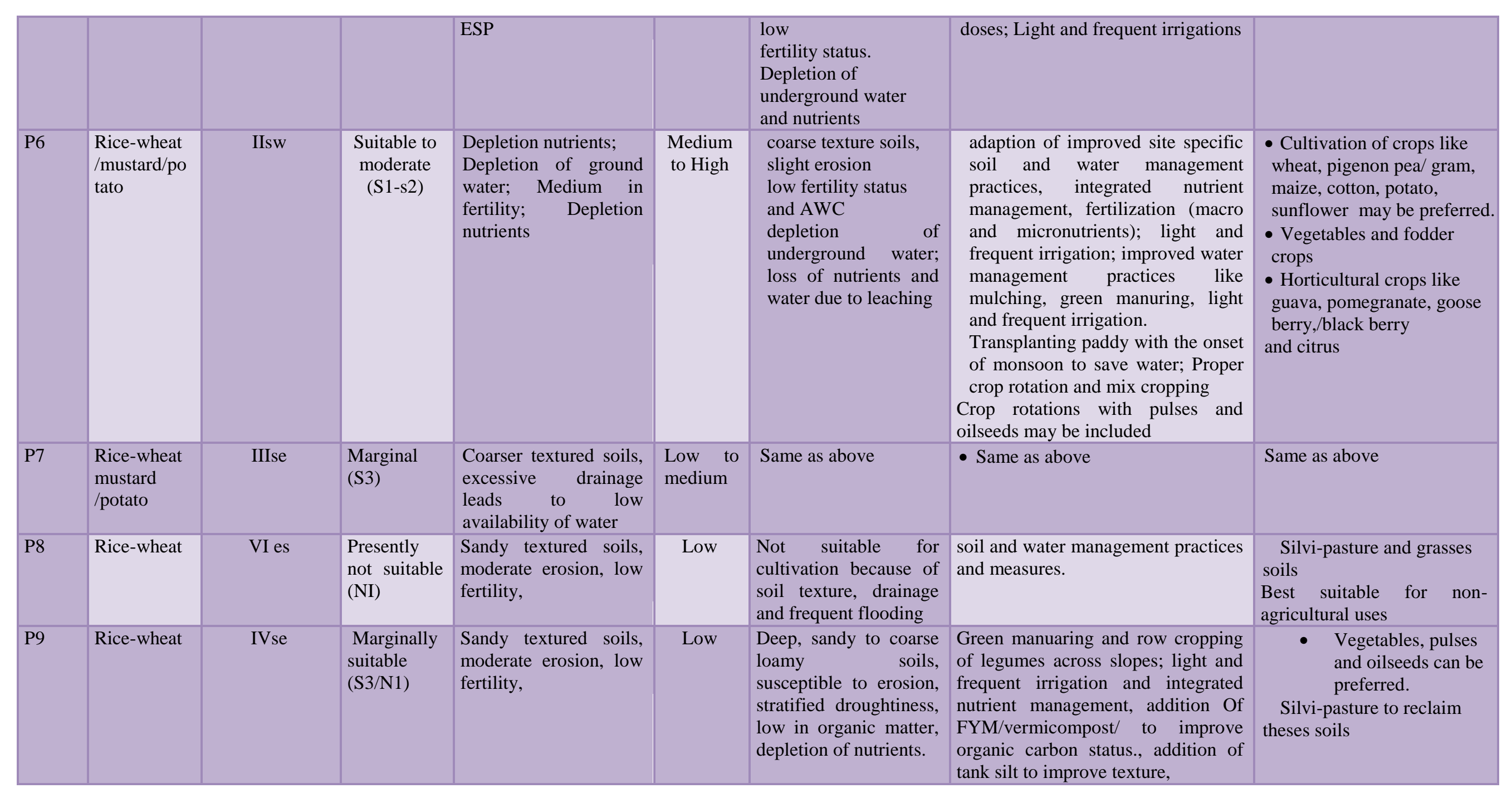


After improving the soil by managing the constraints like $\mathrm{pH}$, texture, wetness and CEC through the addition of recommended doses of fertilizers, amendments like gypsum, organic manures, green manuring with legumes or application of FYM or crop rotation and providing good irrigation facilities/scheduling, these soils can be upgraded to highly suitable category or actual productivity can be improved form good to excellent potential productivity class. For crop like rice, specific needs finer texture, good water and nutrients holding capacity are necessary. Cultivation of rice -wheat on excessively drained soils with poor texture cause poor uptake of nutrients, thus leads to low productivity, decline in water table and natural resources. In such cases, it is better to go for alternate crop like vegetable, pluses, oil seeds. Soil organic carbon status can be alleviated by incorporation of crop residues, compost, trash mulching and inorganic fertilizer in combination with organics. By following these management practices, productivity of these soils can be improved from good to excellent class and suitability can be taken to higher order i.e. moderately suitable (S2) as most of the limitations were manageable. Vegetables, oil seeds and pulses can also be preferred in these soils. Practices to restrict the erosion hazards following soil management practices, actual productivity can be upgraded from low to average to good and good to excellent productivity. Therefore it is suggested to take up alternate crop like vegetables, pulses, oil seeds, mustard and maize crops which suits better for coarser soils with loamy sand texture in pedons having poor or average productivity than for opting rice-wheat which are marginally suitable for rice-wheat crop.

In conclusion, the USDA land capability classification revealed the general suitability of soils are agriculture with limitations. Land evaluation study revealed that characteristics and suitability of these soils for rice-wheat crop were highly variable, hence their management must be site specific. The identified major limitations to rice-wheat crop soil physical and fertility problems. The fertility problems can be corrected/ managed using appropriate measures such as crop rotation with legumes, incorporation of FYM/ compost/ press-mud to increase the organic carbon status and increase the microbial activity so as to enhance the mineralization process. Green manuring with dhaincha to reduce alkalinity, mulching to improve moisture retention capacity and bunding to reduce erosion. These strategies make soils highly and moderately suitable for rice-wheat and potentially suitable crops on sustainable basis.

\section{References}

Anonymous, 2016. Statistical Abstract at a Glance, 2016-17. Ministry of Agriculture, farmers welfare and cooperation. Publ. pg. 449

AIS \& LUS. 1970. Soil Survey Manual. All India Soil and Land Use Survey Organisation. IARI, New Delhi. pp. 163

Black, G. R. and Hartge, K. H. 1986. Bulk Density and Particle Density. In methods of Soil Analysis, Part - 1 (k. Arnold, Ed.) Monograph No.9 Agronomy Series American Society of Agronomy, Inc., Madison, Wisconsin, USA. pp. 363- 382.

FAO., 1976. A framework for land evaluation. Soils Bulletin 32. Food and Agriculture Organization of the United Nations, Rome Italy.

FAO., 1985. Guidelines: land evaluation for irrigated agriculture. Soil Bulletin 55. Food Agriculture Organization of the United Nations, Rome Italy.

FAO., 1993. Guidelines for land-use planning. FAO Development Series 1. 
Food and Agriculture Organization of the United Nations, Rome Italy.

Jackson, M. L. 1973. Soil Chemical Analysis. Prentice Hall of India Private Ltd., New Delhi.

Klingebiel, A. A. and Montgomery, P.H. 1966. Agricultural Hand Book No. 210 USDA, Washington.

Lindsay, W. L., and Norvell, W.A. 1978. Development of DTPA soil test for zinc, iron, manganese and copper, Soil Science Society of America Journal 73, 421-428.

Naidu, L.G.K., Ramamurthy, V., Challa, O., Hegde, R. and Keishanana P. 2006. Manual Soil-Site Suitability Criteria for Major Crops, NBSS Publication No. 129 NBSS \& LUP, Nagpur.

Mahajan, A. and Gupta, R.D. 2009. The ricewheat cropping system. Integrated Nutrient Management (INM) in a sustainable Rice-wheat cropping system. (eds). Springer, Dordrecht DOI:https://doi.org/10.1007/978-14020-9875-8_7

Olsen, S. R., Cole, C. V., Watanabe, F. S. and Dean L. A. 1954. Estimation of available phosphorus in soils by extraction with sodium bicarbonate. United State Department of Agriculture Circular No. 939.

Pillai, K.G. 1994. Current trends in production and productivity and improving rice production. In Proceeding of Symposium on Sustainability of Rice-Wheat Cropping in India (Eds. S.D. Dhimal, M.K. Choudhary, D.V.S. Panwar and K.S. Verma). CCS Haryana Agriculture University, Hisar (India), pp. 14-60.

Riquier, J., Bramo, D.L. and Cornet, J.P. 1970. A New System of Soil Appraisal in terms of Actual and Potential Productivity. FAO, Soil Resource, Development and Conservation Service, Land and Water Development Division,
FAO, Rome. pp. 88-993

Rossiter, D.G. 1996. A theoretical framework for Land Evaluation, Geoderma, 72, 165-190.

G. S. Sidhu (2014) Impact of management levels and land-use changes on soil properties. in rice-wheat cropping system of the. Indo-Gangetic Plains. Current science. Nov 10Volumes/107/09/1487.

G.S. Sidhu, Jaya N. Surya, Tarsem Lal, D. K. Katiyar, J.P. Sharma and Dipak Sarkar (2013) Dynamics of land use and its impact on soil development in Shahid Bhagat Singh Nagar (Nawanshahr district), Punjab state (2013). NBSS Tech. Bull No. 1047.,

Soil Survey Division Staff., 2000. Soil Survey Manual (Indian print), USDA Hand Book No.18, US Govt. Printing office, Washington, DC.

Soil Survey Staff., 2014. Keys to Soil Taxonomy (Twelfth edition) USDA, Natural Resource Conversation Service, Washington, DC.

Surya Jaya N.,_Sidhu, G. S., T. Lal, Katiyar, D.K. and Dipak Sarkar., 2016. Impact of temporal change of land use and cropping system on some soils properties in North-western Parts of Indo-Gangetic Plain. Current Science. Vol.111 (1): 207-212.

Surya, Jaya N. Yadav, R. P., Sidhu, G. S. and S. K. Singh., 2017. Soils of IndoGangetic Plain: Constraints and Potentials under different Agro Ecological Regions. Encyclopedia of Soil Science, Third Edition. CRC Press2016, Pp. 1168-1177.

Surya, J. N., Sidhu G.S., Lal, T., Walia, CS., Katiyar, D.K., Mahapatra, S.K., and R.P. Yadav 2018. Land Resource characterization, soil resource mapping for farm level land use planning - A case study in Upper Gangetic Plains. Int. Jour of Agriculture Sciences. Vol 
10,(16), 6975-6980.

Sys Ir C., Van Ranst, E., Debaveye, J. 1991. Land Evaluation, Part I, Principles in land evaluation and crop production calculations. Inter training centre for post graduate soil scientists, University, Ghent.

Sys, C., Vanranst, E. and Debaveye, J. 1991b. Land evaluation part 11: Methods in land evaluation. General Administration for development cooperation. Agric. Publ. No. 7. Brussels, Belgium, 247 pp.
Van Diepen, C. A., Van Keulan, H., Wolf, J. and Berkhout, J. A. A 1991. Land evaluation from intuition to quantification. Advances in Soil Science (B.A Stewart, Ed.) Springer, New York, pp. 139- 204.

Yadav, R.L. 1996. Cropping systems. In years of Crop Science Research in India, ICAR Publications, pp. 117-120.

\section{How to cite this article:}

Jaya N. Surya, G.S. Sidhu, T. Lal, D. Singh, R.P. Yadav and Singh, S.K. 2019. Land Evaluation of Rice-Wheat Growing Soils of Central Plains of Punjab for Land Use Planning. Int.J.Curr.Microbiol.App.Sci. 8(01): 2590-2601. doi: https://doi.org/10.20546/ijcmas.2019.801.272 